\title{
PEMBERDAYAAN PERAN IBU DALAM PAUD INFORMAL BERBASIS KELUARGA MELALUI PENDAMPINGAN AKTIVITAS IBU DAN ANAK DI RUMAH DENGAN METODE BERMAIN PERAN
}

\begin{abstract}
Lilis Suryani*
Abstract

Informal early child education has not been well developed and there are many mothers who do not understand how to educate a child properly, suitable for the child development and characteristics. Educating the child in the family is rarely done by mother and it becomes more difficult when it has to face mother's domestic daily routine activities which consume a lot of time. This article puts forward a number of reasons why early child education is neglected in the family and purposes how a mother should educate a child properly.
\end{abstract}

Keywords: early child education, child development and characteristics, role playing methods.

\section{PENDAHULUAN}

Pendidikan Anak Usia Dini (PAUD) dilaksanakan dalam tiga jalur. Jalur formal melalui Taman Kanakkanak (TK) dan Raudatul Athfal (RA); jalur nonformal melalui Kelompok Bermain (KB), Taman Penitipan Anak (TPA), dan Satuan PAUD sejenis; serta jalur informal melalui pendidikan dalam keluarga.

Selama ini jalur pertama dan kedua telah cukup berkembang karena telah dilengkapi perangkat pendukungnya, seperti payung kebijakan, aturan main yang jelas, bantuan dana dan peralatan, modul-modul materi, peningkatan kualifikasi pendidik melalui pelatihan atau seminar, serta pemberian insentif atau honor kepada pendidik yang terutama adalah adanya kurikulum untuk jalur formal dan sejenis garis-garis besar pembelajaran yang bersifat general untuk jalur nonformal sebagai panduan kegiatan pembelajaran dan sebagai rujukan operasional di lapangan sehingga pembelajaran dapat dilakukan.

Lalu bagaimana dengan jalur informal? Selama ini jalur informal belum banyak tergali dan belum mendapat perhatian yang cukup. Jalur informal masih mengandalkan pendidikan alamiah yang dilakukan oleh keluarga (terutama ibu) kepada anaknya, baik berupa pewarisan nilai-nilai moral yang dianut oleh keluarga tersebut maupun pengetahuan dan keterampilan dasar. Pelaksanaannya sangat mengandalkan kesadaran atau inisiatif ibu dan tergantung pada pengetahuan serta

* Dosen PAUD FIP UNJ kreativitas ibu dalam mendidik anak. Namun, sebagian besar ibu belum memiliki pengetahuan dan keterampilan mendidik anak yang cukup untuk mengasah potensi putra-putrinya padahal masa usia dini adalah masa yang tepat untuk memberikan stimulasi edukatif kepada anak untuk mengoptimalkan potensi-potensinya.

Dengan demikian, diperlukan edukasi bagi ibu dan panduan-panduan praktis yang dapat dilakukan ibu untuk mendidik anak di rumah. Banyak juga para ibu yang mengakui sungguh sibuk dengan pekerjaan rumah tangga yang harus dilakukan sehingga tidak ada waktu untuk mendidik anak.

Tulisan di bawah ini merupakan salah satu alternatif yang bisa dilakukan ibu di rumah untuk mendidik anak tanpa meninggalkan pekerjaan yang telah menjadi rutinitasnya, yaitu dengan metode bermain peran. Ternyata melakukan pekerjaan rumah tangga sambil bermain dengan anak dapat menjadi sarana belajar yang mendidik dan menarik sekaligus mengakrabkan hubungan emosional ibu dan anak.

Selain itu, gagasan di bawah ini dapat juga menjadi inspirasi bagi pendidik PAUD formal atau nonformal untuk dikembangkan dalam pembelajaran terutama di sentra bermain peran.

Dengan demikian, masalah yang dibahas dalam artikel ini adalah bagaimana memanfaatkan metode bermain peran melalui pendampingan aktivitas ibu dan anak di rumah sebagai sarana belajar untuk anak usia dini? 
Usaha pemerintah dalam memberikan pelayanan pendidikan yang dibutuhkan anak usia dini patut mendapat pujian. Pemerintah berusaha memberikan edukasi PAUD dengan berbagai cara agar PAUD dapat dijangkau semua lapisan masyarakat. Hal itu disampaikan oleh Dirjen PMPTK Dr.Ace Suryadi sewaktu menutup work shop tim akademisi se-Regional I di P2-PNFI Jayagiri, Bandung 16 April 2008 lalu. PAUD dilaksanakan melalui tiga bentuk, yaitu (1) PAUD berbasis industri yang berkembang pada masyarakat kalangan atas di daerah perkotaan; (2) PAUD berbasis masyarakat marginal yang diperuntukkan untuk masyarakat tidak berpunya; dan (3) PAUD berbasis keluarga yang diperuntukkan bagi keluarga yang tidak dapat terjangkau oleh PAUD bentuk kedua sekalipun dengan berbagai macam penyebabnya, misalnya karena domisili yang jauh dipelosok dan tidak ada satupun PAUD memungkinkan untuk di buka di sana atau ekonomi orang tua yang sedemikian tidak mampu walaupun sekedar biaya transpor untuk membawa anaknya ke PAUD (karena pada prinsipnya PAUD bentuk kedua tidak memungut biaya pendidikan) serta membelikan sarana penunjang belajar lainnya atau alasan lain di mana ayah dan ibu bekerja full time sehingga tidak ada waktu untuk mengantar dan menunggu anaknya sedangkan tidak ada orang lain yang dapat mewakilinya. Untuk keluarga dengan kondisi demikianlah maka PAUD bentuk ketiga, yaitu PAUD informal berbasis keluarga diharapkan menjadi pilihan terakhir agar kebutuhan anak usia dini terhadap pendidikan tetap dapat terlayani.

Untuk itu, perlu disiapkan perangkat yang dapat mendukung pelaksanaan PAUD informal berbasis keluarga tersebut. Tindakan yang dapat dilakukan di antaranya sebagai berikut.

1. Memberikan edukasi kepada ibu tentang PAUD.

a. Penyuluhan kepada kaum ibu tentang bagaimana mendidik anak secara praktis dirumah. Hendaknya penyuluh mendatangi tempat tinggal si ibu (jemput bola) atau minimal untuk sekelompok ibu-ibu di tingkat Rukun Tetangga.

b. Penyuluh mendatangi pengajian desa (majelis ta'lim).

c. Bekerja sama dengan posyandu dan Bina Keluarga Balita yang telah ada melalui Pusat Kegiatan Belajar Masyarakat (PKBM) terdekat.

2. Membuat panduan-panduan atau buku mini yang berisi petunjuk praktis mendidik anak.

3. Penyuluh melakukan home visit sebagai tindakan monitoring atau follow up terhadap edukasi yang telah diperoleh ibu, memantau progres dan kesulitan ibu dalam mendidik anak, serta memberikan saransaran konstruktif.

4. Memberikan pelatihan kepada para pendidik PAUD untuk dapat terlatih mengedukasi PAUD kepada orang tua murid atau ibu anak didiknya maupun ibuibu tetangga disekitar tempat tinggalnya yang memiliki anak balita.

Untuk membuat panduan-panduan praktis atau buku mini mendidik anak perlu diupayakan pemikiran dari para pakar di bidang PAUD untuk membuat petunjuk mendidik anak yang sedemikian rupa dapat disesuaikan dan applicable atau dapat diterapkan dengan kondisi masyarakat sasaran. Hal yang dilakukan di antaranya memberikan bahasan yang sederhana dan mudah dimengerti, contoh-contoh penerapan yang dapat ditemui dalam kehidupan sehari-hari, alat bermain yang dapat dibuat sendiri atau murah untuk dibeli, dapat dilakukan dengan waktu yang singkat setiap sesi interaksi bermain ibu-anak, dan mudah dilakukan.

Keluhan yang sering dilontarkan ibu rumah tangga yang tidak bekerja dan mengurus rumah tangga sendiri (tanpa adanya tenaga bantuan orang dewasa seperti kerabat atau keluarga atau pembantu rumah tangga), antara lain adalah sempitnya waktu karena sudah disibukkan dengan pekerjaan rutin rumah tangga sepanjang hari. Kondisi ini lebih sulit untuk ibu yang memiliki anak lebih dari satu, di mana setiap anak membutuhkan perhatian. Dengan demikian, ibu tidak punya waktu untuk mendidik anak balitanya sehingga cukup dengan membuat anak terpaku menonton TV atau bermain sendiri tanpa pengarahan atau menitipkan pada si kakak yang asyik bermain sendiri atau egosentrisnya masih tinggi sehingga mengabaikan si adik agar si ibu bebas melakukan pekerjaannya.

Dengan sedikit usaha dan kemauan terdapat cara untuk mengatasi masalah ini, yaitu melibatkan anak bermain dengan ibu untuk menirukan pekerjaan yang sedang dilakukan ibu. Metode bermain peran (role playing) ini dapat dilakukan tanpa ibu harus meninggalkan pekerjaannya.

\section{Definisi Bermain Peran}

Bermain peran adalah metode pembelajaran yang efektif di mana seseorang memerankan karakter orang lain dan mencoba berpikir atau berbuat dengan cara atau sudut pandang sosok yang diperankannya itu. Bermain peran memberikan contoh alamiah terhadap perilaku manusia yang riil dan dapat digunakan 
oleh anak untuk menyadari perasaan mereka dan membangun sikap menuju nilai-nilai dan pemahaman mereka sendiri (Syah, 1999).

Menurut Gilstrap dan Martin dalam Mayesky (1990), bermain peran adalah memerankan karakter atau tingkah laku dalam pengulangan kejadian yang diulang kembali, kejadian masa depan, dan kejadian masa kini yang penting atau situasi imajinatif. Anakanak pemeran mencoba untuk menjadi orang lain dengan memahami peran untuk menghayati tokoh yang diperankan sesuai dengan karakter dan motivasi yang dibentuk pada tokoh yang telah ditentukan.

Peran diartikan sebagai suatu rangkaian perasaan, ucapan, dan tindakan individu yang ditujukan kepada orang lain. Peran seseorang dalam kehidupan dipengaruhi oleh persepsi dan penilaian oleh dirinya serta orang lain. Untuk dapat berperan dengan baik diperlukan pemahaman tentang peran sendiri mencakup apa yang tampak dan tindakan tersembunyi dalam perasaan, persepsi, dan sikap. Esensi bermain peran ditujukan untuk membantu individu untuk memahami perannya sendiri dan peran yang dimainkan orang lain sekaligus berupaya memahami perasaan, sikap, dan nilai-nilai yang mendasarnya (Moore, 2005).

Pada dasarnya ide utama dari bermain peran adalah untuk menjadi sosok individu yang diperankan dan untuk mendapatkan pemahaman tentang peran tersebut dan motivasi yang berkaitan. Metode ini memberikan kesempatan kepada anak untuk mempelajari tingkah laku manusia. Anak dapat mengeksplorasi perasaan mereka, menghayati persepsi dan tingkah laku orang lain serta belajar terlibat dan berinteraksi dalam proses pembuatan keputusan. (Nurbiana, dkk., 2005)

\section{Tujuan dan Manfaat Bermain Peran}

Mengenai manfaat metode bermain peran, Fledman (1997) mengatakan "In the dramatic play area children have the opportunity to role-play real-life situations, release emotions, practice language, develop social skills, and express themselves creatively". Fledman berpendapat bahwa di dalam situasi dramatik anak-anak memiliki kesempatan untuk bermain peran dalam situasi kehidupan yang sebenarnya, melepaskan emosi, mempraktikkan kemampuan berbahasa, membangun keterampilan sosial, dan mengekspresikan diri dengan kreatif. Menurut Vygotsky, bermain peran mendukung munculnya dua kemampuan penting, yaitu kemampuan untuk memisahkan pikiran dari kegiatan dan benda serta kemampuan menahan dorongan hati dan menyusun tindakan yang diarahkan sendiri dengan sengaja dan fleksibel.

Kegiatan belajar dengan metode ini juga memupuk adanya pemahaman peran sosial dan melibatkan interaksi verbal paling tidak dengan satu orang lain. Penggunaan metode ini membantu anak untuk mempelajari lebih dalam mengenai dirinya sendiri, keluarga, dan masyarakat sekitarnya. Mereka menjalankan perannya berdasarkan pengalamannya yang terdahulu. Mereka belajar memutuskan dan memilih berbagai informasi yang relevan. Hal tersebut sangat membantu mereka dalam mengembangkan kemampuan intelektualnya. Mereka juga banyak belajar dari temannya tentang cara-cara berinteraksi dalam kondisi sosiodramatik (www.interscience.-wiley.com). Selain itu, mereka juga belajar berkonsentrasi dalam satu tema drama untuk waktu tertentu. Area ini juga memberikan kesempatan pada anak untuk mengembangkan kemampuan sosial dan emosionalnya, seperti mengatasi rasa takut dengan memerankan berbagai tokoh yang sebenarnya bagi mereka menakutkan. Misalnya, seorang anak yang takut disuntik memerankan tokoh sebagai pasien. Dengan demikian, metode ini juga berfungsi sebagai katarsis (pelepasan emosi) dan therapist (Isbell, 1995).

Menurut Coughlin (1997) bermain peran berdampak pada beberapa aspek perkembangan anak, yaitu sebagai berikut.

1. Perkembangan sosial. Dengan metode bermain peran anak saling memberikan kontribusinya satu sama lain, anak menempatkan dirinya pada posisi orang lain, memahami arti berhubungan sosial, dan bekerja sama sehingga mendukung perkembangan sosial.

2. Perkembangan emosional. Dengan memainkan suatu peranan akan tumbuh rasa percaya diri anak, mengenal bentuk-bentuk emosi (seperti berharap, takut, dan marah), anak menghayati perasaan dirinya dan orang lain, menghargai jasa sesama, serta mengenal kekuatan dan kelemahan dirinya.

3. Perkembangan intelektual. Dalam bermain peran anak belajar untuk membuat hubungan-hubungan, mengorganisasi informasi, memahami pola, menguji idenya melalui proses coba-ralat (trial and error) atau 
eksperimen (percobaan), memformulasi dan menentukan rencana, menyesuaikan ide dengan waktu; saat ini, masa lalu, dan masa mendatang menggunakan ingatannya ke dalam suatu kejadian atau jalan cerita, menggunakan peralatan, serta mainan dan media yang sesuai dengan tujuan. Di dalam kegiatannya hal-hal tersebut juga mengembangkan konsep sains dan matematika. Secara singkat, bermain peran mendukung perkembangan intelektual, kreativitas, dan kemampuan berpikir kritis.

Smilansky dalam E. Berk (1994) mengemukakan setelah mempelajari tentang inisiatif mandiri anak dalam kegiatan sosiodrama atau bermain peran menyimpulkan "Socio-dramatic play behavior develops three main areas in a child, all of which are essential parts, not only of play, but also of the school game and the game of life". Bermain sosiodrama membangun tiga area penting pada diri anak yang merupakan bagian-bagian yang penting tidak hanya bermain tetapi juga permainan atau simulasi sekolah dan permainan atau simulasi kehidupan. Ketiga area itu adalah sebagai berikut.

1. Kreativitas. Berdasarkan pengalaman yang sudah dilalui anak dan dikendalikan dalam bingkai kerja skenario yang direncanakan bersama guru dan anak. Caranya adalah dengan mendiskusikan dan menggali ide-ide dari anak-anak sehingga memperkaya ide dasar menjadi satu pemahaman yang sama. Kesempatan untuk bermain imajinatif, percakapan spontan, dan tindakan yang kreatif sebaiknya dibuka seluas-luasnya untuk membangun kreativitas anak.

2. Perkembangan intelektual dan bahasa. Dalam kegiatan ini anak mengabstraksi, memperkaya konsep, dan mendapatkan pengalaman baru. Dalam bermain sosiodrama, anak berbagi ide dan konsep tentang dunia di sekitar mereka. Bahasa menjadi penting di sini di mana anak-anak dengan bebas menggunakan bahasa sehingga kemampuan berbahasa mereka semakin berkembang.

3. Keterampilan sosial. Sosiodrama mengandung nilainilai positif tentang memberi dan menerima, toleransi, dan kebijaksanaan. Keterampilan sosial terbangun dalam episode kehidupan keluarga dan masyarakat, anak harus hidup bekerja sama dengan manusia lain dalam mencapai tujuan bersama.

Penuturan dan teori dari para ahli di atas tentunya dapat menjadi landasan atau pijakan kuat untuk merealisasikan kegiatan ini. Adapun menurut Suryani, dkk. (2007) tujuan bermain peran antara lain sebagai berikut.
1. Anak dapat mengeksplorasi perasaan-perasaan.

2. Memperoleh wawasan (insight) tentang sikap-sikap, nilai-nilai, dan persepsinya.

3. Mengembangkan keterampilan dan sikap dalam memecahkan masalah yang dihadapi.

4. Mengembangkan kreativitas dengan membuat jalan cerita atas inisiatif anak.

5. Melatih daya tangkap.

6. Melatih daya konsentrasi.

7. Melatih membuat kesimpulan.

8. Membantu pengembangan kognitif.

9. Membantu perkembangan fantasi.

10. Menciptakan suasana yang menyenangkan.

11. Mencapai kemampuan berkomunikasi secara spontan atau berbicara lancar.

12. Membangun pemikiran yang analitis dan kritis.

13. Membangun sikap positif dalam diri anak.

14. Menumbuhkan aspek afektif melalui penghayatan isi cerita.

15. Untuk membawa situasi yang sebenarnya ke dalam bentuk simulasi atau miniatur kehidupan.

Menurut Maxim (1989) kelebihan metode bermain peran antara lain sebagai berikut.

1. Melibatkan anak secara aktif dalam pembelajaran yang dibangunnya sendiri.

2. Anak memperoleh umpan balik yang cepat atau segera.

3. Memungkinkan anak mempraktikkan keterampilan berkomunikasi.

4. Sangat menarik minat dan antusiasme anak.

5. Membuat ibu atau guru dapat memberikan pembelajaran sambil bermain pada ruang lingkup yang luas dalam mengoptimalkan kemampuan banyak anak pada waktu yang bersamaan.

6. Mendukung anak untuk berpikir kritis dan analitis.

7. Menciptakan percobaan situasi kehidupan dengan model lingkungan yang nyata.

\section{Tahap-tahap Perkembangan Bermain Peran}

Bermain peran merupakan suatu aktivitas anak yang alamiah karena sesuai dengan cara berpikir anak usia dini, yaitu berpikir simbolik (menurut teori Piaget). Banyak ahli yang meneliti dan memberi perhatian terhadap aktivitas anak ini dan menghasilkan penemuan dan teori yang menjadi dasar keilmuan bagi kajian bermain peran, antara lain tahap-tahap perkembangan bermain peran diambil dari Research in Review: The Early Development of Symbolic Play Young Children (1995) yang digambarkan di dalam tabel di bawah ini secara konkret. 
Tabel 1. Tahap Perkembangan Bermain Peran

\begin{tabular}{|c|c|c|c|}
\hline No & KATEGORI & URAIAN & CONTOH \\
\hline 1. & Awal pura-pura & $\begin{array}{l}\text { Anak terlibat dalam tindakan seperti } \\
\text { pura-pura tetapi belum ada bukti dia } \\
\text { main pura-pura }\end{array}$ & $\begin{array}{l}\text { Anak sekilas menyentuh telepon ke } \\
\text { telinga, sekilas menempelkan botol } \\
\text { ke mulut boneka }\end{array}$ \\
\hline 2 & Pura-pura dengan dirinya & $\begin{array}{l}\text { Anak terlibat dalam perilaku pura- } \\
\text { pura, diarahkan pada dirinya sendiri, } \\
\text { di mana pura-pura terlihat jelas }\end{array}$ & $\begin{array}{l}\text { Anak mengangkat cangkir ke bibir } \\
\text { dan menyentuh cangkir membuat } \\
\text { suara sedang minum }\end{array}$ \\
\hline 3 & $\begin{array}{l}\text { Pura-pura dengan yang } \\
\text { lain }\end{array}$ & $\begin{array}{l}\text { Anak terlibat dalam perilaku pura- } \\
\text { pura, diarahkan oleh anak kepada } \\
\text { yang lainnya; perilaku pura-pura } \\
\text { tentang orang lain }\end{array}$ & $\begin{array}{l}\text { Anak memberi makan boneka } \\
\text { dengan botol bayi mainan atau } \\
\text { cangkir; mendorong truk di atas } \\
\text { lantai, dan membuat kegaduhan }\end{array}$ \\
\hline 4 & Pengganti & $\begin{array}{l}\text { Anak menggunakan objek seadanya } \\
\text { dalam cara yang kreatif atau sesuai } \\
\text { khayalan atau menggunakan objek } \\
\text { dalam cara yang berbeda dari } \\
\text { biasanya }\end{array}$ & $\begin{array}{l}\text { Anak memberi makan boneka } \\
\text { menggunakan balok sebagai botol; } \\
\text { meletakkan sepotong lilin atau play } \\
\text { dough dalam piring dan } \\
\text { menyebutnya sebagai kue }\end{array}$ \\
\hline 5 & $\begin{array}{l}\text { Pura-pura dengan objek } \\
\text { atau orang }\end{array}$ & $\begin{array}{l}\text { Anak pura-pura bahwa objek, bahan, } \\
\text { orang atau binatang itu ada }\end{array}$ & $\begin{array}{l}\text { Anak menuang teko kosong ke } \\
\text { cangkir dan berkata, "Kopi," } \\
\text { bergerak seputar ruangan } \\
\text { membuat suara motor, seolah-olah } \\
\text { sedang mengendarai sepeda motor }\end{array}$ \\
\hline 6 & Agen aktif & $\begin{array}{l}\text { Anak menghidupkan mainan (seperti } \\
\text { boneka dan binatang mainan) yang } \\
\text { mewakili sesuatu sehingga mainan } \\
\text { menjadi agen yang aktif di dalam } \\
\text { kegiatan pura-pura }\end{array}$ & $\begin{array}{l}\text { Anak melompat-lompatkan } \\
\text { binatang mainan dengan satu kaki } \\
\text { melewati karpet seolah-olah } \\
\text { binatang itu sedang berlari, } \\
\text { menaruh tangan boneka ke mulut } \\
\text { boneka seolah-olah boneka itu }\end{array}$ \\
\hline 7 & $\begin{array}{l}\text { Urutan yang belum } \\
\text { berbentuk cerita }\end{array}$ & $\begin{array}{l}\text { Anak mengulang-ulang satu tindakan } \\
\text { atau adegan kepada beberapa orang }\end{array}$ & $\begin{array}{l}\text { Anak memberi ibu secangkir } \\
\text { minuman kemudian memberikan } \\
\text { bonekanya secangkir minuman }\end{array}$ \\
\hline 8 & Urutan cerita & $\begin{array}{l}\text { Anak menggunakan lebih dari satu } \\
\text { adegan dalam main peran }\end{array}$ & $\begin{array}{l}\text { Anak mengaduk cangkir, minum } \\
\text { dari cangkir, dan berkata "mmm, } \\
\text { rasanya enak" }\end{array}$ \\
\hline 9 & Perencanaan & $\begin{array}{l}\text { Anak terlibat dalam main peran } \\
\text { dengan bukti ada perencanaan lebih } \\
\text { dahulu }\end{array}$ & $\begin{array}{l}\text { Anak berkata bahwa ia akan } \\
\text { memberi makan bayi sebelum } \\
\text { meletakkan botol minum bayi ke } \\
\text { mulut boneka }\end{array}$ \\
\hline
\end{tabular}

\section{Urgensi Mendidik Anak melalui Pendampingan Aktivitas lbu di Rumah dengan Metode Bermain Peran}

Ada beberapa urgensi mengapa mendidik anak melalui pendampingan aktivitas ibu dengan metode bermain peran ini menjadi penting untuk dilakukan, antara lain sebagai berikut.

1. Bermain peran adalah permainan yang sesuai dengan tingkat perkembangan kognitif anak usia dini

Anak usia dini yang dimaksudkan dalam tulisan ini adalah berusia antara tiga sampai enam tahun, artinya bermain peran dengan mendampingi aktivitas ibu di rumah dapat dilakukan seputar usia anak mendekati tiga tahun sampai menjelang tujuh tahun. Pada usia tersebut kebanyakan anak belum tersentuh pendidikan dasar; ibu sebagai pendamping utama anak dalam setiap aktivitasnya. Menurut Piaget pada usia dua sampai tujuh tahun anak berada pada masa praoperasional, yaitu anak berpikir simbolik dengan daya khayalnya menghadirkan representasi dunia nyata ke dalam dunia imajinasinya. Dengan demikian, bermain peran sangat sesuai dengan pola berpikir anak pada saat ini (Essa, 2003). 
2. Bermain peran adalah jenis permainan yang di gemari anak

Dengan karakteristik anak pada usia dini yang menyenangi dunia khayal dan bermain pura-pura, anak akan terdorong dengan sendirinya dan memiliki motivasi internal untuk bermain karena anak dapat menjadi apa saja yang ia inginkan. Secara otomatis anak akan senang menghabiskan waktu bermain seiring dengan bermunculan ide dan dialog yang berkembang sepanjang proses bermain tersebut.

3. Dimensi-dimensi perkembangan anak berkembang secara simultan dalam bermain peran.

Bermain peran dapat membantu mengembangkan potensi-potensi perkembangan anak, seperti intelektual, bahasa, sosial-emosi, kreativitas, moral, life skill, dan fisik dalam waktu yang bersamaan. Studi yang pernah penulis lakukan tentang wayang suket sebagai media bermain peran menghasilkan temuan bahwa bermain peran dapat meningkatkan kecerdasan jamak anak (multiple intelligences).

4. Anak tidak terabaikan dan mendidik anak tetap dapat berjalan

Dengan bermain peran didampingi ibu, hak anak untuk mendapatkan perhatian, bimbingan, dan pendidikan dasar dari ibu tetap terpenuhi. Secara psikologis anak yang merasa diperhatikan oleh ibu akan memiliki kepribadian yang lebih sehat serta percaya diri dibandingkan dengan anak yang merasa terabaikan. Pengabaian anak merupakan salah satu bentuk kekerasan pada anak (child abuse), yaitu penelantaran emosi yang akan berdampak negatif terhadap pertumbuhan dan perkembangan anak selanjutnya.

5. Bermain peran mudah dilakukan oleh ibu dan anak secara bersamaan atau Ibu mendampingi anak bermain tanpa harus meninggalkan pekerjaan rumah tangga yang tengah dilakukannya

Bermain peran ini dapat dilakukan ibu-anak karena mudah dimengerti dan mudah dilakukan (dengan cara anak meniru perbuatan ibu dan dialog yang alamiah) tanpa harus dengan persiapan yang rumit. Pada waktu bersamaan ibu dan anak melakukan kegiatan paralel, yakni ibu dengan aktivitas sesungguhnya sedangkan anak dengan aktivitas bermain peran atau bermain pura-pura sehingga tidak menunda waktu ibu untuk mengerjakan pekerjaan rumahnya.

Ibu dapat mengajak anak bermain menjadi ibu dengan sedikit pengarahan awal. Bahkan pekerjaan ibu dapat menjadi inspirasi anak untuk meniru apa yang sedang diperbuat ibu pada saat itu. Tentunya sepanjang bermain, sambil mengerjakan pekerjaannya, ibu dapat terus berdialog dengan anak tentang apa yang tengah anak lakukan bahkan berkembang menjadi percakapan yang menghidupkan bermain peran itu sendiri. Dengan demikian, di samping anak bermain ibu dapat terus melakukan pekerjaannya.

6. Ibu tetap dapat mengawasi atau menjaga anaknya dan memastikannya dalam keadaan aman

Dengan tetap melakukan pekerjaannya, ibu selalu terlibat dengan aktivitas anak di sampingnya sehingga secara otomatis ibu dapat terus menjaga anak dan memastikannya dalam keadaan aman.

7. Hanya memerlukan alat-alat bermain sederhana berukuran mini

Alat-alat bermain peran dapat dibuat sendiri secara kreatif, menggunakan alat-alat rumah tangga yang telah ada atau dapat dibeli dengan harga murah.

8. Mengakrabkan hubungan emosi dan membangun kedekatan ibu-anak

Pekerjaan rumah tangga yang tidak habis-habis telah menyita sebagian besar waktu ibu bersama anak. Dengan melibatkan anak dalam pekerjaan ibu, ibu tetap dapat menjalin kontak komunikasi yang intens dengan anak, dan ibu tidak kehilangan moment-moment bersama anak sehingga kedekatan dan keakraban ibuanak dapat terbangun.

9. Menumbuhkan kepedulian anak terhadap peran ibu di rumah dan menumbuhkan keinginan untuk membantu

Dengan terlibat dalam bermain peran sebagai ibu, anak akan menghargai jasa-jasa ibu kemudian peduli terhadap peran ibu dan akhirnya tumbuh keinginan untuk membantu. Tentunya ini adalah niat baik anak yang perlu ibu hargai walaupun ibu tahu bahwa bantuan anak terkadang memperpanjang pekerjaannya tetapi ini akan menjadi wujud bantuan yang sebenarnya ketika kemampuannya sudah cukup untuk itu atau bila ia sudah dewasa kelak.

10. Merupakan langkah awal untuk melatih keterampilan melakukan pekerjaan-pekerjaan rumah tangga sederhana

Saat ini banyak "anak kota" yang tidak dapat mengerjakan pekerjaan-pekerjaan rumah tangga karena dari kecil ia tidak diperkenalkan dengan itu. Padahal itu adalah keterampilan hidup atau life skill yang berguna dimanapun ia berada, apalagi bila telah mandiri kelak. Dengan bermain peran ini anak mengenal pekerjaanpekerjaan rumah tangga seperti menyapu, belanja, dan mencuci piring walaupun pada tingkat pura-pura, artinya memang bukan ditujukan untuk menyelesaikan pekerjaan rumah tangga yang sebenarnya tetapi dasar keterampilan untuk itu telah mulai terbangun dengan bermain peran ini. 


\section{Bebas gender}

Banyak opini masyarakat yang merasa risih bila anak lelaki bermain dengan boneka atau bermain purapura memasak, membersihkan rumah, mencuci, dan menyetrika karena dianggap hal-hal seperti itu berbau feminim. Keterampilan ini bukan dominasi anak perempuan, boneka dapat menumbuhkan daya khayal, kreativitas dan katarsis emosi (bonekapun beragam jenisnya, dari teddy bear sampai boneka hero), memasak, mencuci, membersihkan rumah, dan menyetrika perlu ia kuasai ketika ia menjadi anak kos atau tinggal di asrama kelak harus mandiri dan tidak ada orang lain yang dapat diandalkan untuk mengerjakan pekerjaan-pekerjaan itu. Lagipula, keterampilan hidup apapun tidak ada ruginya untuk dipelajari karena pasti akan berguna suatu saat kelak. Dengan demikian, bermain peran ini tetap sesuai baik untuk anak perempuan maupun laki-laki.

12. Menumbuhkan sikap-sikap positif, seperti cinta kebersihan, bertanggung jawab, disiplin, dan rajin

Dengan menghayati peran melakukan pekerjaanpekerjaan ibu akan tumbuh pada anak perasaan untuk selalu bersih, rajin, bertanggung jawab terhadap tugas, dan disiplin mengatur waktu.

Dari pemaparan alasan di atas maka dapat dimengerti bahwa bermain peran ini merupakan alternatif yang perlu dipertimbangkan dan dilakukan.

\section{Pelaksanaan}

1. Prinsip-prinsip dalam bermain peran ibu dan anak

Sebelum memulai bermain peran, hendaknya ibu perlu mengingat hal-hal di bawah ini untuk membangun kemampuan-kemampuan anak dalam bermain peran, yaitu sebagai berikut.

a. Dalam kegiatan ini anak bermain bukan untuk memperingan pekerjaan ibu

Seyogianya ibu menyadari tujuan bermain adalah berada dalam proses kegiatan bukan pada akhir kegiatan atau bukan menuntut produk. Manfaat bermain peran terjadi saat proses bermain itu berlangsung (seperti menimbulkan rasa senang pada diri anak dan menumbuhkan inisiatif atau motivasi intrinsik) sehingga kegiatan ini bukan berarti anak membantu ibu menyelesaikan pekerjaan agar cepat selesai (ini adalah tujuan bekerja yang berbeda dengan tujuan bermain). Kemampuan dan keterampilan anak usia tiga sampai enam tahun belum cukup untuk mengerjakan pekerjaan rumah tangga dengan benar dan tentunya kita tidak mau momen bermain ini malah menjadi beban yang dirasakan anak. Kegiatan anak dalam bermain peran ini hanya sebatas pura-pura melakukan hal yang sama dilakukan oleh ibu dengan media boneka atau alat-alat bermain peran.

b. Ibu perlu menghidupkan imajinasinya

Bermain peran adalah dunia khayal dan dunia pura-pura. Oleh karena itu, ibu perlu berkhayal atau menghidupkan imajinasi dalam pikirannya agar bisa memahami dan menyelami apa yang sedang dikhayalkan anak pada saat bermain peran. Jangan membenturkan pada kenyataan dan menafikan khayalannya dengan berkomentar yang meruntuhkan imajinasi anak seperti: "Ah, bohong, mana mungkin kamu dapat jalan-jalan ke bulan!". Akan lebih baik bila ibu memperkaya imajinasi anak, misalnya dengan berkata: "Oh,ya? Wow, hebat! Lalu kamu ketemu makhluk apa di bulan? Sama siapa saja kamu kesana? Ibu ikut tidak?". Bila anak sudah merasa matching seperti ini maka anak merasa antusias bermain peran dan permainan pun akan dapat berjalan optimal.

c. Berikan kesempatan yang luas untuk bebas anak bereksplorasi pada waktu bermain peran

Kegiatan bermain peran akan lebih optimal apabila anak diberi kesempatan untuk bermain dan bereksplorasi dengan alat-alat yang ada sehingga kegiatan ini akan lebih efektif bila membebaskan anak untuk menentukan jalan cerita secara spontan, bebas menggunakan alat-alat, bebas memerankan siapa saja, dan bebas berdialog. Dengan demikian, kreativitas anak akan lebih terasah.

d. Anak bebas menentukan waktu bermain

Tentunya pekerjaan ibu yang sebenarnya memakan waktu yang lama untuk diselesaikan. Anak tidak perlu bermain peran selama itu namun sesuka hati selama ia belum bosan. Dengan demikian, ibu menghidupkan suasana dengan terlibat dialog dalam bermain peran anak ketika mengerjakan pekerjaannya. Berikan variasi instruksi dan alternatif alat bermain peran. Bila itu pun gagal, anak tidak harus menyelesaikan pekerjaannya karena memang inilah sifat bermain, ia bebas memulai dan bebas menghentikannya. Berikan alternatif kegiatan lain yang anak sukai selain bermain peran.

e. Mendukung tindakan anak dengan memberikan komentar atau pertanyaan pancingan dari ibu

Untuk anak yang lebih kecil di mana kemampuan berbicaranya belum begitu optimal, ibu mungkin perlu bertanya atau membuat pernyataan yang menegaskan tindakan yang dilakukan anak pada saat itu, teknik ini juga bertujuan memperkaya ide-ide anak dalam bermain peran. Menurut Read dan Patterson (1980) perhatian ibu dapat mendukung perilakunya dalam bermain peran, seperti berikut. 
Tabel 2. Contoh Dukungan dan Perhatian Ibu terhadap Anak

\begin{tabular}{|l|l|}
\hline Ibu melihat anak... & Ibu bisa berkata... \\
\hline Berbaring di atas bantal selama waktu bermain & "Oh, ceritanya ini bayi yang kecapekan..?" \\
\hline $\begin{array}{l}\text { Mengambil gelas kosong dan berpura-pura } \\
\text { minum }\end{array}$ & "Hhmm, aku yakin rasanya pasti enak, ya..?" \\
\hline Merangkak berputar sambil menyalak & $\begin{array}{l}\text { "wah, anjing yang cantik sekali.. Apakah kamu } \\
\text { menyalak karena lapar? }\end{array}$ \\
\hline Mendorong boneka bayi di troli belanja & $\begin{array}{l}\text { "apakah kamu dan bayimu belanja untuk } \\
\text { makan malam?" }\end{array}$ \\
\hline
\end{tabular}

Komentar dan pertanyaan seperti itu selain akan mengenalkan anak pada perbuatan yang dilakukannya juga akan memancing anak untuk berbicara dan juga memperkaya imajinasi anak.

f. Menggunakan variasi teknik yang lain selain dialog, yaitu meniru (mimetics)

Mimetics adalah latihan fisik dengan meniru gerakan yang sudah dikenal tanpa peralatan yang biasanya dipakai untuk aktivitas tersebut. Melalui mimetics anak meniru gerakan orang lain dan binatang atau mesin. Anak-anak perlu menggunakan imajinasi mereka atau berpura-pura menggunakan peralatan yang sesuai (Herr, 2001). Contohnya ialah sebagai berikut.

1) Menangkap kupu-kupu.

2) Memanjat tembok.

3) Melata seperti ular.

4) Menggali parit.

5) Melompat seperti kodok.

6) Memetik bunga.

7) Mengayuh sepeda.

8) Merayap seperti laba-laba.

9) Berkelahi dengan pedang.

Tidak ada unsur menerka dalam kegiatan ini, berbeda dengan pantomim yang mengandung unsur menerka melalui gerakan yang diperagakan. Kegiatan ini mendukung perkembangan kognitif terutama perkembangan fisik.

g. Menyadari kelemahan dari kegiatan ini

Di samping kelebihan dan manfaat dari kegiatan bermain peran berdampingan dengan aktivitas ibu, ibu perlu secara arif menyadari dan menerima beberapa kelemahan dari kegiatan ini walaupun bersifat hanya kemungkinan saja, antara lain sebagai berikut.

1) Kegiatan ibu sering kali terinterupsi dengan pertanyaan-pertanyaan anak, misalnya sewaktu menyetrika, "Ibu bagaimana caranya melipat sapu tangan ini?", sewaktu memasak: "Ibu, sayur-sayurannya terus mau diapain?". Berilah petunjuk sederhana "Coba, tirulah Ibu..", selanjutnya ibu dapat melanjutkan pekerjaannya kembali. Saat ini anak sedang belajar, untuk itu ibu sebaiknya bersabar menghadapinya.

2) Penyelesaian pekerjaan ibu menjadi lebih lambat. Ibu jangan merasa kehadiran anak malah menjadi merepotkan pekerjaannya memang anak belajar butuh proses waktu. Dengan sedikit bersusah payah pada masa ini, ibu akan menuai "buahnya" di kemudian hari, yaitu life skill anak menjadi terasah dan mendapatkan manfaat-manfaat lain yang telah dijelaskan di atas. Selain itu, ketika kemampuannya dan usianya sudah cukup, ia akan terbiasa dan senang hati membantu ibu melakukan pekerjaan yang sebenarnya.

3) Meminimalisasi hal-hal yang dapat merugikan anak. Minta anak untuk tidak berlama-lama mencuci baju bonekanya (bermain air) sewaktu menirukan ibu mencuci baju untuk menghindari rasa dingin yang menyebabkan flu atau minta anak untuk membantu menyapu (berpura-pura menyapu) area rumah yang ibu tahu tidak terlalu kotor atau berdebu untuk menghindari batuk atau bersin dan jauhkan anak sedikit dari kompor yang menyala ketika bermain masak-masakan di dapur, sejauh jarak pandang anak masih dapat mengamati atau menirukan hal-hal yang dilakukan ibu ketika memasak.

2. Langkah-langkah bermain peran

Langkah-langkah bermain peran di bawah ini terinspirasi dari buku The Creative Curriculum (Domro, 2001), Creating and Managing Learning Centers: $A$ Thematic Approach (Ingraham, 1997), dan Squish, Sort, Paint \& Build: Over 200 Easy Learning Center Activities (MacDonald, 1996), yakni sebagai berikut.

a. Berikan pemanasan berupa ajakan dan petunjuk bermain

Berikanlah ajakan yang menarik kepada anak dan petunjuk bermain yang praktis. Misalnya, 
"Eh kak, kita main menjadi ibu-ibuan yuuk... Kakak menirukan ibu menyetrika ya. Ini setrikaan kakak (terbuat dari plastik) dan ini baju-baju yang harus disetrika (sapu tangan dan baju boneka), supaya si "Barbie" bajunya licin, seperti baju kakak kalau mau pergi, ya kan?"

b. Tentukan lingkup bermain peran anak dan lingkup pekerjaan ibu

Misalnya pada kegiatan memandikan adik, sampaikan pada anak, ibu memandikan adik dan ia memandikan si upik (bonekanya) dengan menirukan ibu. Begitu pula kalau kegiatan yang akan dilakukan adalah memasak, ibu akan memasak masakan ibu, lalu dapat ditanyakan anak akan memasak apa hari ini? Dengan demikian itulah yang akan ia lakukan.

c. Sediakan variasi alat-alat dan media pendukung yang memberikan inspirasi dan siapkan peralatan bermain peran yang sesuai dengan kegiatan

Dengan adanya beragam mainan maka anak akan bereksplorasi menggunakan mainan-mainan tersebut sesuai dengan peran yang dibawakannya sehingga imajinasi dan kreativitas anak juga akan berkembang (Miller dan Gibbs 2002). Untuk perlengkapan bermain peran yang sederhana, anak dapat membuatnya sendiri (dengan bimbingan dari ibu) sehingga juga melatih motorik halus anak, misalnya topi badut, dan wayang atau gambar ditempel pada stik ice cream.

Alat-alat bermain peran yang dapat disediakan antara lain sebagai berikut.

1) Kaca besar.

2) Kompor.

3) Baju-baju.

4) Meja setrika.

5) Telepon.

6) Stetoskop.

7) Sapu, tempat sampah dan pel.

8) Tempat tidur boneka, stroler boneka, dan ayunan.

9) Beragam boneka.

10) Topi.

11) Tas.

12)Alat-alat makan (piring, sendok, dan mangkuk).

13)Kaleng kosong,

14)Peralatan ibu guru (kapur, kacamata, dan tongkat penunjuk),

15)Peralatan tukang.

16)Peralatan bengkel.

Alat bermain perlu disesuaikan dengan kegiatan yang akan dilakukan. Misalnya, kegiatan yang akan dilakukan adalah memandikan adik maka ibu siapkan boneka plastik, bak kecil, spons, dan handuk beserta alat-alat mandi lain untuk bermain peran bila kegiatannya memasak maka yang disiapkan untuk anak adalah satu perangkat alat bermain masak-masakan; buah, sayur, panci, kompor, dan pisau plastik.

Selain alat-alat bermain di atas, anak juga dapat menggunakan boneka dan wayang. Dalam kegiatan ini anak menjadi sang sutradara atau dalang, anak bebas menentukan jalan cerita, dialog, dan tokoh-tokohnya. Teknik ini sangat mendukung perkembangan bahasa, kreativitas, dan imajinasi karena anak bebas mengendalikan permainan dan bebas berekspresi.

d. Biarkan anak melakukan monolog atau dialog dengan spontan

Salah satu kemampuan anak yang dapat berkembang melalui bermain peran adalah kemampuan berbahasa. Dalam bermain peran anak akan mempersonifikasi tokoh-tokoh dalam khayalannya melalui dialog di antara bonekabonekanya sedangkan ia sebagai dalangnya. Oleh karena itu, ibu jangan terlalu heran kalau mendengarnya berbicara sendiri, dalam dunia khayalnya banyak tokoh yang sedang berbicara silih berganti, kreativitas berbicara pun akan berkembang melalui dialog-dialog yang ia ciptakan sendiri menjadi suatu rangkaian cerita yang unik. Pada saat ini sebaiknya ibu "terjun" ke dalam khayalannya dengan melibatkan diri berdialog sehingga memperkaya fantasinya, misalnya berpura-pura menjadi salah satu tokoh.

e. Buka kesempatan berkomentar secara informal antara ibu-anak

Menurut teori Zone of Proximal Development dari Vygotsky, (dalam E. Berk and Adam Winsler, 2001) anak akan mengaktualisasi potensinya dengan bantuan dari orang dewasa (ibu) dan temanteman sebaya yang mempunyai kemampuan lebih. Dengan demikian, perlu ada percakapan informal antara ibu-anak yang mengomentari atau menjelaskan setiap adegan, percakapan, dan perbuatan anak agar anak memahami pesan yang dimaksud dari adegan tersebut. Peran ibu sangat penting untuk selalu terlibat dialog selama bermain peran untuk menjaga keterlibatan dan menghidupkan suasana pura-pura. Ibu bisa tetap berbicara sambil terus mengerjakan pekerjaannya. f. Minta pendapat anak tentang karakter tokoh yang diperankannya

Ibu dapat meminta pendapat anak tentang tokoh yang diperankan usai bermain. Dengan 
memainkan peran tokoh itu, karakter tokoh tersebut tentunya telah dirasakan melekat pada diri anak sehingga anak memiliki pandangan sendiri tentangnya. Tentu saja ibu dapat memberikan penekanan sifat positif yang harus ditiru dan sifat negatif yang harus dihindari dari peran tersebut, setelah anak berpendapat. Cara seperti ini dapat mengembangkan kemampuan sosial anak, yaitu menumbuhkan sikap simpati dan empatik terhadap peran tersebut dan juga mengenal beragam emosi dari karakter-karakter peran yang ditampilkan.

\section{g. Buat kesimpulan bersama}

Melalui diskusi ini ibu dan anak bersama menyimpulkan tentang jalan cerita dan karakter tokoh-tokohnya. Tujuan dari diskusi ini adalah menekankan kembali nilai-nilai sosial dan moral yang terkandung dalam cerita dan semestinya di teladani anak. Dengan demikian, diharapkan karakter-karakter positif itu dapat terbiasa dalam tingkah laku anak sehari-hari ketika bersosialisasi dengan orang lain.

h. Tanamkan kebiasaan tanggung jawab dan disiplin seusai bermain

Minta kepada anak untuk membereskan dan merapikan kembali alat-alat bermain dengan dibantu ibu untuk menanamkan sikap tanggung jawab dan menjaga kerapihan kembali seusai bermain maka hidup teratur akan menjadi kebiasaannya.

3. Contoh kegiatan

\section{a. Memasak}

Masak-masakan adalah permainan yang disukai anak dan anak mengenal dengan baik, karena melihat setiap hari ibu memasak di dapur. Sekarang saatnya anak terlibat di dapur, memasak bersama ibu.

1) Manfaat: mengenal buah-buahan, sayursayuran, lauk-pauk dan manfaatnya, proses pengolahan makanan, fungsi api, alat-alat masak dan fungsinya, serta penyajian makanan dan juga melatih motorik halus anak.

2) Peralatan mainan: seperangkat mainan masak-masakan yang terbuat dari plastik; kompor, plastik, penggorengan, buah-buahan, sayur-sayuran, ayam, dan pisau plastik. Disarankan mainan dari kayu (buah, sayur, dan roti kayu) yang sudah siap terbelah bila dipotong oleh pisau kayu namun dapat direkatkan kembali. Dapat juga dimanfaatkan daun-daunan yang tidak terpakai untuk dipotong-potong.

3) Cara bermain: Ibu mengajak anak bermain di dapur menggunakan mainan masak-masakan dengan ajakan yang menarik. Ibu menjelaskan hal-hal yang akan ibu lakukan dan bertanya apa yang akan dilakukan anak. Ibu dapat memberikan ide bila anak tidak memiliki ide bermain (misalnya ibu dapat meminta anak menirukan langkah-langkah ibu memasak bila anak belum tahu harus berbuat apa; tentunya ibu dengan masakan sungguhan dan anak dengan mainannya). Mulailah bermain. Selama bermain terus adakan interaksi yang kontinu baik berupa meniru perbuatan atau tanya jawab atau komentar. Untuk anak yang sudah lebih besar atau terbiasa, biarkan ia mengembangkan imajinasinya sendiri, ibu hanya perlu mengomentari langkah-langkah yang ia lakukan sesekali saja. Selesai bermain, simpulkan apa yang dilakukan anak dan berpura-puralah memakan hasil masakan anak dan pujilah hasil usahanya itu.

4) Antisipasi: hindarkan anak dari menggunakan alat-alat masak yang sebenarnya, seperti pisau dan kompor (api). Jaga jarak aman antara anak dengan kompor. Jelaskan bahaya dan manfaat alat-alat itu kepada anak sebagai tindakan preventif.

b. Memandikan dan memakaikan baju adik bayi Anak balita suka cemburu terhadap kehadiran adik barunya karena menurut pandangannya perhatian dan kasih sayang ibu beralih kepada adik baru dan ia merasa dikesampingkan. Bermain mengurus boneka bayi dapat mengubah perasaan negatif menjadi kompensasi positif dan dapat menumbuhkan perasaan sayang kepada adik.

1) Manfaat: pelampiasan atau katarsis emosi secara positif, menumbuhkan keterikatan emosional dengan adik dan menumbuhkan rasa tanggung jawab sebagai kakak, mengetahui hal-hal yang perlu dan tidak perlu dilakukan dalam mengurus adik, serta menumbuhkan daya imajinasi.

2) Peralatan mainan: boneka bayi plastik, ember kecil, spons, handuk kecil, tempat bedak dan botol minyak telon kosong, baju boneka, dan sisir.

3) Cara bermain: ajaklah anak bahwa kita akan bermain memandikan dan memakaikan baju adik bayi. Ibu mengurus si adik sementara si anak mengurus bonekanya. Terlebih dahulu mintalah anak menyiapkan alat-alatnya (dibantu ibu). Mulailah bermain, ibu memandikan adik bayi, anak memandikan 
bonekanya, dari membasuh, menggunakan sabun, membersihkan dengan spons sampai membilas, dan mengeringkan dengan handuk. Adakan interaksi komunikasi terus menerus antara ibu-anak selama proses. Bila anak belum tahu langkah-langkah melakukannya, minta anak untuk menirukan ibu. Ciptakan suasana kebersamaan yang mengasyikkan. Proses diakhiri dengan ibu memakaikan baju adik dan anak memakaikan baju bonekanya. Jangan lupa tanyakan perasaan anak dalam melakukan permainan itu (review) dan tekankan nilai-nilai positif (bahwa kita harus menyayangi adik)

4) Antisipasi: hindarkan anak untuk memandikan atau memakaikan baju adik bayi yang sesungguhnya karena kemampuan anak belum bisa untuk itu. Bila perlu pun, cukup memberi bantuan-bantuan kecil di bawah pengawasan ibu (seperti mengambilkan baju adik dan membentangkan kain perlak) untuk menghindari hal-hal yang tidak diinginkan.

\section{c. Mencuci baju}

Anak paling suka bermain air. Ibu tidak perlu overprotektif karena ada hal-hal bermanfaat yang didapat anak dengan bermain air, apalagi ada tindakan manipulatif yang dapat anak lakukan dengan bermain air itu, misalnya mencuci baju dengan air (mencuci yang dimaksud di sini adalah dengan cara tradisional).
1) Manfaat: anak mengenal basah dan kering, mengenal sifat-sifat air (seperti dapat melarutkan, mengalir dari tempat tinggi ke tempat rendah, dan berubah bentuk sesuai bentuk wadahnya), serta melatih motorik halus (seperti melipat, membalik pakaian, memeras, dan mengucek).

2) Peralatan mainan: baju-baju boneka, saputangan, penggilesan kecil, ember kecil, dan plastik sabun kosong.

3) Cara bermain: Ajaklah anak dengan ajakan yang menarik, siapkan peralatan ibu dan anak dengan mainannya. Mulailah ibu menyuci dan anak bermain, ibu dapat meminta anak menirukan langkah-langkah yang ibu lakukan, dari merendam, mengucek, membilas, dan memeras sampai menjemur. Sediakan juga mainan alternatif lain jika ia sudah bosan sementara ibu masih mencuci, misalnya botol-botol kosong yang dapat ia isi air dan tumpahkan, batu apung, dan batu kerikil. Simpulkan kembali nilai-nilai edukatif yang ia dapat diakhir permainan, seperti batu $A$ mengapung karena ringan dan batu $B$ tenggelam karena berat.

4) Antisipasi: hindarkan sabun detergen dan sebaiknya anak tidak terlalu lama bermain air.

Contoh-contoh kegiatan lain yang dapat dijadikan kegiatan bermain peran, seperti mencuci piring, menyetrika, berbelanja ke pasar, dan menyapu.

\section{KESIMPULAN}

Setelah mengikuti penguraian ini, tentunya kita sampai pada kesimpulannya ternyata pekerjaan ibu melalui bermain peran dapat menjadi sumber belajar yang sesuai dengan anak usia dini. Selain itu, kegiatan ini bahkan membantu mengoptimalkan potensipotensinya, seperti kreativitas, imajinasi, motorik halus, intelektual, bahasa, dan emosi yang sangat diperlukan untuk keberhasilan setiap tahapan tumbuh kembang anak selanjutnya. Pekerjaan rutinitas ibu di rumah tidak menjadi halangan untuk mendidik anak bahkan dapat mengakrabkan hubungan ibu-anak. Dengan demikian, masa keemasan anak (the golden age) tidak terlewat (tersia-siakan) begitu saja tepat di depan mata ibu.

Kepada pihak berwenang (dalam hal ini direktorat yang terkait dengan PAUD dan Pendidikan NonformalInformal) diharapkan untuk membuat sistem yang integral dari tataran tingkat pusat sampai daerah untuk mensosialisasikan alternatif cara mendidik anak secara informal ini, termasuk mencetak buku-buku mini mendidik anak praktis berlandaskan ide ini untuk para kaum ibu rumah tangga di pelosok desa dan kota. Kepada para pendidik PAUD diharapkan dapat menularkan ide ini kepada orang tua murid untuk mendidik anak di rumah. Selanjutnya, kepada pakar PAUD di jajaran akademik diharapkan dapat terus mengembangkan ide dasar ini yang tentunya masih memerlukan penelitian dan perbaikan sehingga gagasan ini menjadi semakin lengkap dan siap pakai. 


\section{DAFTAR PUSTAKA}

Coughlin, P.A, et.al. (1997). Creating child-centered classrooms: 3-4 age year olds. Washington DC: Children Resources International, Inc.

Dhieni, N., dkk. (2005). Metode pengembangan bahasa. Jakarta: Universitas Terbuka.

Dombro, A.L. (2001). The creative curriculum. Washinton DC: Teaching Strategies.

E.Berk, L. \& Winsler, A. (2001). Scaffolding children's learning, vygotsky \& early childhood education volume 7. NAEYC Research into Practice Series.

E.Berk, L. (1994). Child development. Boston: Allyn \& Bacon.

Essa, E.L. (2003). Introduction to early childhood education. New York: Thomson-Delmar Learning.

Feldman, J.R. (1997). Wonderful rooms where children can bloom!. Peterborough, NH: Crystal Springs.

Herr, J. (2001). Creative learning activities for young children. New York: Delmar.

Ingraham, P.B. (1997). Creating and managing learning centers: A thematic approach. Peterborough, $\mathrm{NH}$ : Crystal Springs Books.

Isbell, R. (1995). The complete learning center book. Beltsville, MD: Gryphon House.
MacDonald, S. (1996). Squish, sort, paint \& build: Over 200 easy learning center activities. Beltsville, MD: Gryphon House.

Maxim, G.W. (1989). The very young. New York: MacMillan publishing company.

Mayesky, M. (1990). Creative activities for young children. New York: Delmar Publisher Inc.

Miller, L.G., \& Gibbs, M.J. (2002). Making toys for preschool children. Beltsview, MD: Gryphon House.

Moore, K.D. (2005). Effective instructional strategies. London: Sage Publications.

Psychodrama and sociodrama in primary and secondary education.(www.interscience.-wiley.com).

Read \& Patterson (1980). The nursery school \& kindergarten. $7^{\text {th }}$ ed. New York: Holt, Rinehart and Winston.

Research in Review. (1995). The early development of symbolic play young children.

Syah, M. (1999). Psikologi pendidikan dengan pendekatan baru. Bandung: Remaja Rosdakarya.

Suryani, L., dkk. (2007). Metode pengembangan kemampuan dasar dan perilaku anak usia dini. Jakarta: Universitas Terbuka. 